\title{
Biomass Gasification Process with Catalyst
}

\author{
H Musfer
}

Chemical engineering, Cardiff University

To Cite this Article

$\mathrm{H}$ Musfer, "Biomass Gasification Process with Catalyst", International Journal for Modern Trends in Science and Technology, 6(9): 38-53, 2020.

\section{Article Info}

Received on 06-August-2020, Revised on 20-August-2020, Accepted on 25-August-2020, Published on 30-August-2020.

\section{ABSTRACT}

Gasification is a thermo-chemical process used to convert biomass fuelsinto a fuel gas. Biomass gasification is considered amongst the best methods to enhance biomass-based energy production's efficiency as it allows common biomass utilization.It has become more important as a mean of converting low energy-density such as biomass feeds or into a transportable high value gas for heat and power generation, chemicals and fuels.

Operating conditions are affecting the gasification reactions. the review identified that in high-temperature gasification, endothermic reactions the secondary cracking and reforming of heavy hydrocarbons are favored and hence enhances the whole process's efficiency.

Finally, catalysts are vital for the biomass gasification process, and it is important to select the appropriate ones taking into consideration possible setbacks discussed above and will be explored further in this study.

KEYWORDS: Gasification, biomass, date stone, catalyst.

\section{INTRODUCTION}

Gasification is a thermo-chemical process used to convert biomass fuels (date stone in this study) into a fuel gas. For example, 'date stone' is the biomass fuel tested in this paper. Subsequently, It can be used to produce chemical products and the generation of both heating and electricity [1].

Biomass gasification is considered amongst the best methods to enhance biomassbased energy production's efficiency as it allows common biomass utilization [2]. It has become more important as a mean of converting low energy-density such as biomass feeds or into a transportable high value gas for heat and power generation, chemicals and fuels [3].

The Biomass gasification process consists of three stages. The first stage is 'upstream processing' which ensures the biomass's size reduction to a suitable a particle size and drying it to an appropriate moisture level. The second stage involves the actual gasification process which will be explored in further details in this paper. the final stage is the downstream process and the clean-up of the gas product [4].

The most important stage is the gasification step which is considered to be the heart of the entire process. It utilises a thermal chemical reaction to convert the used biomass into combustible gas in a controlled environment, while using different gasifying agents such Oxygen, Carbon Dioxide or in the presence of air. Therefore, the gasification process is underdone in a gasifier, in which the biomass undergoes a sequence of physical and chemical transformations as well as combustion through oxidation.

Generally, gasification is split into four steps: drying (endothermic reaction), pyrolysis (endothermic reaction), oxidation (exothermic reaction), and reduction (endothermic reaction) [5]. 
They are shown in Figures (1) and (2) and explained further as following:

- Drying: In this stage, biomass's moisture is evaporated by drying. The evaporated material contributes to chemical reactions at later stage. According to Hamad et al. between 10-15\% of moisture is reduced by drying [6].

- Pyrolysis: as mentioned above, it is an endothermic reaction and it is considered to be the first step in the gasification process. Unlike combustion, pyrolysis occurs in the absence of oxygen, except for when it is done through a partial combustion, as a way to supply the needed energy in these processes [7].

Biomass is heated to remove the volatile components which forms about $70 \%$ to $86 \%$ of a dried biomass [8]. The pyrolysis yield production is dependent on various factors; namely the type of the used biomass, moisture content, and particle size, reaction temperature, reaction time, heating rate, carrier gas type and the flow rate of carrier gas, catalyst, and reactor type [9].

At $300{ }^{\circ} \mathrm{C}$ and higher, the biomass pyrolysis takes place in the same site where the moisture was produced from the drying process (the first step), it also completes with $\mathrm{H} 2, \mathrm{CO}, \mathrm{CO} 2, \mathrm{CH} 4$, and tar (devolatilization) which are needed for full pyrolysis [10].

According to Guedes et al.[11], the pyrolysis is split into three forms which arises from the used operating conditions. The forms are slow, fast and flash pyrolysis.

Generally, about $70 \%$ to $86 \%$ of the biomass is converted to volatile materials in the form of gases and liquids, and its residual is named char, which consists of carbon and ash [12].

- Combustion: gasification contains a chain of exothermic and endothermic reactions. Thermal energy which is required for the endothermic reaction is gained from combustion of biomass, gases or char rely on the design of the reactor to maintain thermal efficiency [2].

Gasification: It follows the pyrolysis step and utilises the pyrolysis gases, pyrolysis tars, and char residues. The latter is partially oxidised using the pre-existing gasifying agent at high temperatures roughly between $600{ }^{\circ} \mathrm{C}$ to $1500{ }^{\circ} \mathrm{C}$, yielding mainly hydrogen $(\mathrm{H} 2)$, carbon monoxide $(\mathrm{CO})$, carbon dioxide $(\mathrm{CO} 2)$, methane $(\mathrm{CH} 4)$ and traces of ethane and propane. Furthermore, tar and char are the outcomes of the incomplete reaction of biomass [13].

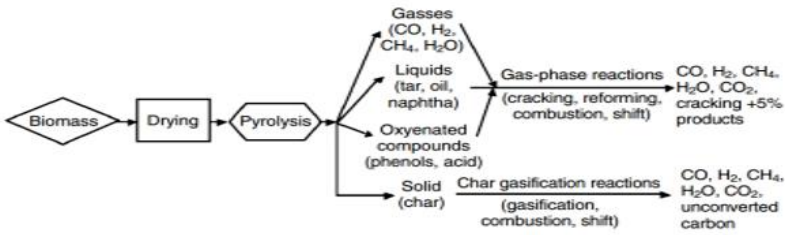

Figure 1Schematic steps of biomass gasification[14]

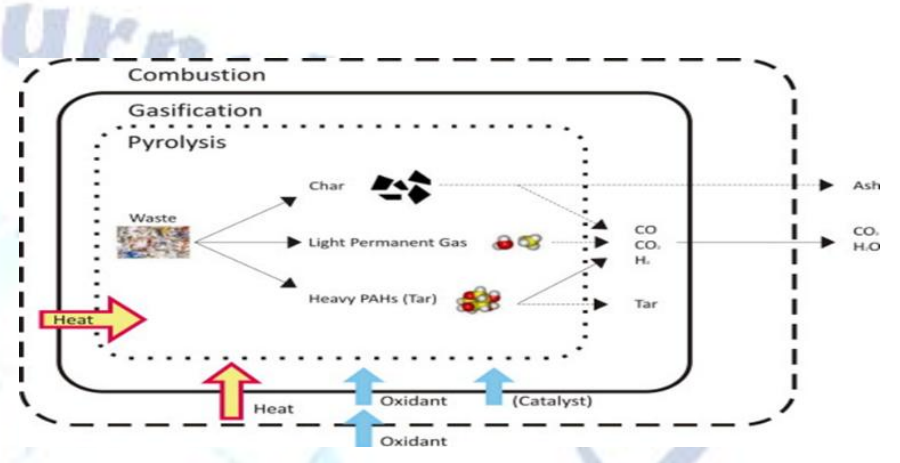

Figure 2: Schematic representation thermochemical process[15].

Several thermal processes occur in the gasification step. Moreover, various exothermic and endothermic reactions occur between carbon, carbon dioxide, steam, and hydrogen in the gasifier, if the appropriate operation conditions are met.

As a result of the reversible nature of the gasification reactions, the direction, and conversion of the reactions, a thorough understanding of the reaction kinetics and thermodynamics is needed to maintain the overall efficiency at an acceptable rate.

The efficiency and quality of the produced gas relies on several parameters, mainly on thermodynamic equilibrium coefficient of the gasification reactions. The main chemical reactions taking place in the gasifier are described in the next section.in preventing damage to the joint and optimized performance.

\section{Biomass Gasification Reactions}

As mentioned above, the biomass undergoes a sequence of endothermic and exothermic reactions. The contrast of both reaction types creates an environment suitable a complete gasification process at an adequate efficiency. Below is the description of each reaction, while a breakdown of the reactions is showing in Table (1). 
Table 1: A breakdown of the biomass gasification reactions occurring in the gasifier.

\begin{tabular}{|c|c|c|c|c|}
\hline Number & Type & Reaction & Reaction Name & $\begin{array}{l}\text { Heat of } \\
\text { reaction } \\
(\mathrm{MJ} / \mathrm{kmol})\end{array}$ \\
\hline R1 & $\begin{array}{l}\text { Biomass } \\
\text { Pyrolysis }\end{array}$ & $\begin{array}{l}\text { Biomass Char+ Tar }+\mathrm{H} 2 \mathrm{O} \\
+ \text { Light gas } \\
(\mathrm{CO}+\mathrm{CO} 2+\mathrm{CH} 4+\mathrm{H} 2+\mathrm{O} 2+ \\
\mathrm{N} 2+\ldots)\end{array}$ & $\begin{array}{l}\text { Biomass } \\
\text { devolatilization }\end{array}$ & $>0$ \\
\hline $\mathrm{R} 2$ & \multirow{5}{*}{$\begin{array}{l}\text { Oxidation } \\
\text { reactions }\end{array}$} & $\mathrm{C}+1 / 2 \mathrm{O} 2 \rightarrow \mathrm{CO}$ & $\begin{array}{l}\text { Carbon partial } \\
\text { oxidation }\end{array}$ & -111 \\
\hline R3 & & $\mathrm{CO}+1 / 2 \mathrm{O} 2 \rightarrow \mathrm{CO} 2$ & $\begin{array}{l}\text { Carbon monoxide } \\
\text { oxidation }\end{array}$ & -283 \\
\hline $\mathrm{R} 4$ & & $\mathrm{C}+\mathrm{O} 2 \rightarrow \mathrm{CO} 2$ & Carbon oxidation & -394 \\
\hline R5 & & $\mathrm{H} 2+1 / 2 \mathrm{O} 2 \rightarrow \mathrm{H} 2 \mathrm{O}$ & Hydrogen oxidation & -242 \\
\hline R6 & & $\begin{array}{l}\mathrm{CnHm}+\mathrm{n} / 2 \mathrm{O} 2 \leftrightarrow \mathrm{nCO} \\
+\mathrm{m} / 2 \mathrm{H} 2\end{array}$ & $\begin{array}{l}\text { CnHm partial } \\
\text { oxidation }\end{array}$ & Exothermic \\
\hline $\mathrm{R} 7$ & \multirow{4}{*}{$\begin{array}{l}\text { Gasification } \\
\text { reactions } \\
\text { involving } \\
\text { steam }\end{array}$} & $\mathrm{C}+\mathrm{H} 2 \mathrm{O} \leftrightarrow \mathrm{CO}+\mathrm{H} 2$ & $\begin{array}{l}\text { Steam reforming } \\
\text { water-gas reaction }\end{array}$ & +131 \\
\hline $\mathrm{R} 8$ & & $\mathrm{CO}+\mathrm{H} 2 \mathrm{O} \leftrightarrow \mathrm{CO} 2+\mathrm{H} 2$ & $\begin{array}{l}\text { Water- gas shift } \\
\text { reaction }\end{array}$ & -41 \\
\hline R9 & & $\mathrm{CH} 4+\mathrm{H} 2 \mathrm{O} \leftrightarrow \mathrm{CO}+3 \mathrm{H} 2$ & $\begin{array}{l}\text { Steam methane } \\
\text { reforming }\end{array}$ & +206 \\
\hline R10 & & $\begin{array}{l}\mathrm{CnHm}+\mathrm{nH} 2 \mathrm{O} \leftrightarrow \mathrm{nCO}+(\mathrm{n} \\
+\mathrm{m} / 2) \mathrm{H} 2\end{array}$ & Water-gas reaction & Endothermic \\
\hline $\mathrm{R} 11$ & \multirow{2}{*}{$\begin{array}{l}\text { Gasification } \\
\text { reaction } \\
\text { involving } \\
\text { Hydrogen }\end{array}$} & $\mathrm{C}+2 \mathrm{H} 2 \leftrightarrow \mathrm{CH} 4$ & $\begin{array}{l}\text { Hydrogen } \\
\text { gasification }\end{array}$ & -75 \\
\hline $\mathrm{R} 12$ & & $\mathrm{CO}+3 \mathrm{H} 2 \leftrightarrow \mathrm{CH} 4+\mathrm{H} 2 \mathrm{O}$ & Methanation & -227 \\
\hline $\mathrm{R} 13$ & \multirow{2}{*}{$\begin{array}{l}\text { Gasification } \\
\text { reaction } \\
\text { involving } \\
\text { carbon dioxide }\end{array}$} & $\mathrm{C}+\mathrm{CO} 2 \leftrightarrow 2 \mathrm{CO}$ & Boudouard reaction & +172 \\
\hline R14 & & $\begin{array}{l}\mathrm{CnHm}+\mathrm{nCO} 2 \leftrightarrow \mathrm{n} \\
2 \mathrm{nCO}+\mathrm{m} / 2 \mathrm{H} 2\end{array}$ & Dry reforming & Endothermic \\
\hline R15 & \multirow{2}{*}{$\begin{array}{l}\text { Decomposition } \\
\text { reaction of } \\
\text { tars and } \\
\text { hydrocarbons }\end{array}$} & $\mathrm{pCxHy} \rightarrow \mathrm{qCnHm}+\mathrm{rH} 2$ & Dehydrogenation & Endothermic \\
\hline R16 & & $\mathrm{CnHm} \rightarrow \mathrm{nC}+\mathrm{m} / 2 \mathrm{H} 2$ & Carbonization & Endothermic \\
\hline
\end{tabular}

\section{Water-gas reaction (R2.7)}

This a heterogeneous reaction that occurs between carbon and steam at a high temperature. The reaction produces carbon monoxide and hydrogen as following:

$\mathrm{C}+\mathrm{H} 2 \mathrm{O} \rightarrow \mathrm{H} 2+\mathrm{CO}$

It is worth mentioning that this reaction is an endothermic one, therefore it needs continuous heating to maintain the produced gasses.

\section{Boudouard reaction (R2.13)}

It is a heterogeneous reaction between carbon dioxide and carbon molecules in high temperatures, typically higher than $700^{\circ} \mathrm{C}$ and atmospheric pressure; as following:

$\mathrm{C}+\mathrm{CO} 2 \rightarrow 2 \mathrm{CO}$ 
Furthermore, the product of this reaction increases when increasing the temperature above than 700 ${ }^{\circ} \mathrm{C}[16]$.

\section{Water-gas shift reaction (R2.8)}

This is a homogeneous reaction between carbon monoxide and water in vapour case $(\mathrm{CO}+\mathrm{H} 2 \mathrm{O} \leftrightarrow \mathrm{CO} 2+\mathrm{H} 2)$. This reaction is exothermic and used to increase the hydrogen content and minimize carbon monoxide in the product gas.

\section{Methanation reaction (R2.12)}

In this reaction, methane is produced from hydrogen and carbon or carbon dioxide. This reaction is categorized as the exothermic reaction. However, the best condition for this reaction is high pressure and low temperature. Finally, methane is the required gas in combustion process due to it has higher heating value comparing to carbon monoxide or hydrogen [3].

\section{Steam methane reforming reaction (R2.9)}

This reaction considers as a homogeneous (gas-gas), high endothermic reaction and reversible.

\section{BIOMASS GASIFICATION PRODUCTS}

Gasification and combustion are defined as the chemical processes which converts carbon-based materials (e.g. biomass) into either chemical feedstock or gaseous fuels. The produced material would consist of both product gasses and bio-syngas, as showing in Figure (3).

However, the product of biomass gasification exhibits differences in terms of heating value. Unlike combustion, the energy stored in the chemical bounds is not rapidly released, instead it is packed [7]. The process's products are described below.

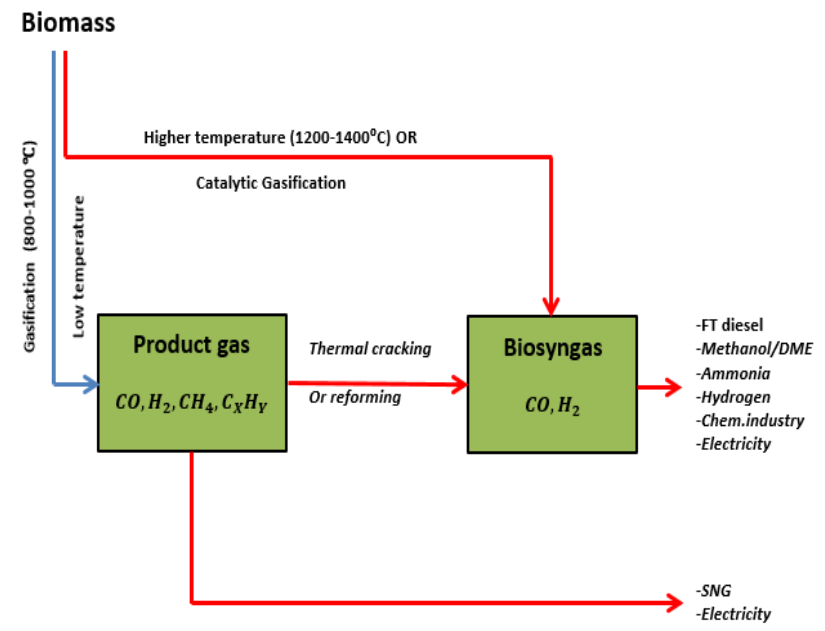

Figure 3: The main difference and their typical applications between 'product gas' and 'bio-syngas'

- Product gas: it is produced when the temperature in the gasification processes is less than $1000^{\circ} \mathrm{C}$. It contains $\mathrm{CO}, \mathrm{H} 2, \mathrm{CH} 4, \mathrm{CxHy}$ aliphatic hydrocarbons, benzene, toluene, and tars (beside $\mathrm{CO} 2$ and $\mathrm{H} 2 \mathrm{O}$ ).

$\mathrm{H} 2$ and $\mathrm{CO}$ in the syngas contains approximately $50 \%$ of the energy, while the rest is contained in $\mathrm{CH} 4$ and higher (aromatic) hydrocarbons [17]. Product gas used mainly in home heating and electricity generation [18].

- Bio-syngas: There are two different ways that biomass gasification can yield bio-syngas:

(1) It can be produced via the biomass gasification process without a catalyst presence and in in high temperature; usually higher than $\left.1200{ }^{\circ} \mathrm{C}\right)$.

(2) Alternatively, catalytic gasification can be used to produce the bio-syngas instead.

In both ways, the biomass is fully converted into $\mathrm{H} 2$ and $\mathrm{CO}$ (alongside $\mathrm{CO} 2$ and $\mathrm{H} 2 \mathrm{O}$ ). Therefore, bio-syngas can be used in all fossil fuel application, due to the chemical similarities regardless of the source (i.e. whether it is derived from fossil or biomass sources).

\section{KEY FACTORS AFFECTING THE GASIFICATION PROCESS}

Many factors affect the product gas's quality such as composition, gasification performance, and its energy content [19]. These all are dependent on the process's operational conditions, gasifier configuration, and raw materials origin [19]. It is remarkable to know which parameters affect the 
quality of the production from gasification processes. A figure of gasification parameters will be demonstrated.

\section{Operating conditions}

During biomass gasification, the operation conditions play a significant role in the whole process [20]. It affects various key parameters such as the used tar formation, carbon conversion, tar reduction, and production gas structure [20]. The most important operating conditions are the bed temperature, ER, the used gasification agent, feeder location, static bed height, and particle size. The conditions will be discussed in more details in the following sections.

\section{Bed Temperature}

Bed temperature is considered among the most important operation parameters. Mainly as it affects both the produced gas composition and the resultant heating value [21].

The structure of the product gas via gasification relies on the bed temperature of the reactor. Increasing the bed temperature in the gasifier increases the resultant heating value, the combustible gas content, hydrogen content and gas yield, however it would reduce the tar content dramatically [22].

Jin Woo Kook et al. [22] reported that tar content can be reduced by several methods, either by increasing the temperature or change the feeding position. It was observed that increasing the temperature inside the gasifier from $720{ }^{\circ} \mathrm{C}$ to 825 ${ }^{\circ} \mathrm{C}$ increases the gas yield from $2.1 \mathrm{~m} 3 / \mathrm{kg}$ to 2.7 $\mathrm{m} 3 / \mathrm{kg}$, as the carbon conversion of biomass increases [23]. Furthermore, Maria Cortazar et al. [24] reported that higher temperatures have a positive effect on carbon conversion, gas yield, and tar removal, and hence the overall increased efficiency of the process. They studied the effects of increasing the temperature from $800{ }^{\circ} \mathrm{C}-900{ }^{\circ} \mathrm{C}$ and they found that the concentration of tar fell from $49.2 \mathrm{gNm}-3$ to $6,7 \mathrm{gNm}-3$.

Moreover, the hydrogen yield rose by $7.28 \mathrm{wt} \%$ at $900{ }^{\circ} \mathrm{C}$. From the material mass balance, the amount of $\mathrm{CO}$ and $\mathrm{H} 2$ increased with the increased temperature, as promoted endothermic water-gas and Boudouard reactions in the gasifier. On the other hand, $\mathrm{CO} 2$ decreases with the higher temperature, while the concentration of $\mathrm{CH} 4$ remains relatively stable [25].

Ebubekir et al. [26] investigated the gasification of pinecones particles and wood pellets [26]. Their experiments have shown that the percentage of produced $\mathrm{H} 2$ and $\mathrm{CO}$ in the yield grows by increasing reactor temperature.

Behashti et al. [27] used Aspen Plus simulators and dedicated FORTRAN subroutines to investigate the bed temperatures further. They developed a process simulation for gasification of biomass in a bubbling fluidized bed for hydrogen and syngas production, the result of that is the high temperature is more suitable for production useful syngas(H2 and $\mathrm{CO})$ [27].

In summary, various research have proven that the bed temperature is directly proportional to the yielded product [21][22][23][24][25][26][27]. Therefore, it is vital to ensure that the temperatures are high enough to obtain optimum efficiency.

\section{Equivalent Ratio (ER)}

The Equivalence ratio (ER) is the ratio between the actual gasification agent (air or oxygen) to fuel divided by the stoichiometric condition, it can be calculated using the following formula [28].

$\boldsymbol{E} \boldsymbol{R}=($ air $/$ biomass $)$ a $/$ (air $/$ biomass $)$ s

Pyrolysis, gasification, and combustion all represent the varied thermochemical zones. The zones can be seen shown when plotting ER against temperature, as shown in Figure (4) [28]. According to Ghassemi, [29] the amount of $\mathrm{H} 2$ is shows an inverse proportion with ER As due to the presence of $\mathrm{O} 2$ in the system, leading to Hydrogen oxidation.

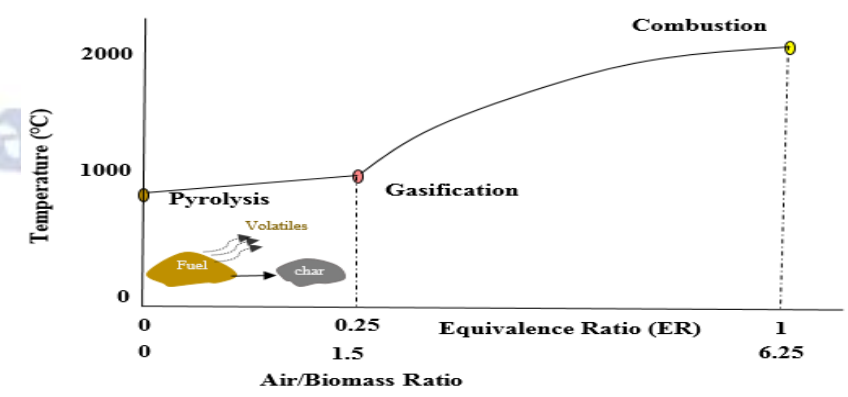

Moreover, the ratio of $\mathrm{CO}$ in the product increases when the ER increase, however it later declines [29], as a result of increasing ER which lowers the heating value predicted in the product gas [30]. 
Notably, the production of $\mathrm{CO} 2$ is high in case of higher ER values, due to the formation of a strong oxidation reaction.

Figure 4 Equivalence Ratio and Air/ fuel diagram

This process and at high ER values yields the energy needed to satisfy the endothermic reactions needed for an efficient biomass gasification process [28][29].

\section{Gasification Agent}

In the gasification process, numerous gasifying agents are used. They are often consisting of oxygen, air, carbon dioxide, hydrogen in appropriate rations [31]. The ratio of the gasification agents helpscategorising the gasification product according toits lower heating value (LHV) which relies on the type of gasifying agent employed as explained in Table (2) [32].

\begin{tabular}{|l|l|l|}
\hline $\begin{array}{l}\text { LHV } \\
\text { level }\end{array}$ & $\begin{array}{l}\text { LHV } \\
\text { (MJ/N } \\
\mathrm{m} 3)\end{array}$ & Gasifying agent \\
\hline Low & low 4-6 & Using air and air/ stem \\
\hline $\begin{array}{l}\text { Medi } \\
\text { um }\end{array}$ & $\begin{array}{l}\text { High } \\
10-15\end{array}$ & using O2/ steam \\
\hline High & $\begin{array}{l}\text { High } \\
15-20\end{array}$ & using H2 \\
\hline
\end{tabular}

Table(2): Classifications of producer gas according to lower heating value.

Shayan et al. [33] carried out biomass gasification experiments using wood and paper as a feedstock with four different gasification agents: air, oxygen-enriched air, oxygen, and steam. The results indicate that the higher values of hydrogen is produced when using steam, followed by oxygen, oxygen-enriched air, and air as the gasification agents [33].

According to Mustafa et al. [34] the best gasifying agent is Oxygen, but it is more costly. Additionally, the gasification process turns to combustion in the case of a high concentration of oxygen, which leads to the production of "flue gas" instead of "fuel gas". various researchers reported that the most optimum gasifying agent from an economical aspect is steam, as it leads to more Hydrogen yield [35]. Pinto et al. [36] studied the effect of the different gasifying agents (Mixtures of air, oxygen, steam, and $\mathrm{CO} 2$ with different compositions of two or more components) with the waste of rice like (rice husk and straw and plastics). The results showed that the best technical option was a mixture of oxygen and steam, as it was not diluted in Nitrogen causing a $42 \%$ increase in the heating value [37].

\section{Location of Feeding.}

The distribution of product gas is affected by the location of biomass feeding, according to Sikarwar et al. [38]. Mainly, there are two locations of feeding; updraft which allows the fuel to enter from the top of the gasifier and the gasification agent from the bottom [38]. The second is downdraft which both the fuel and gasifying agent enter from the top [38].

There are a few differences in each feeding location set up. In downdraft gasifier feeding, the product from pyrolysis passes through a hole bed which supplies an efficient mixing of the product gases [39]. On the other hand, the amount of tar in downdraft is reduced due to cracking through the bed, which increase the yield of $\mathrm{H} 2$ and $\mathrm{CO}$ [39]. Nevertheless, the latter feeding position requires low moisture content presence; ideally less than $25 \mathrm{wt} \%$, in the exhaust dust and ash are present, and an important point it consider as very attractive due to low tar in the product, easy operation and fabrication [40]. The benefit of using the updraft is its simplicityand high-energy efficiency due to active internal heat exchange [41]. Hanif et al. [42] reported the capacity of updraft could be high as a result of low temperate of the product leaving the gasifier.

In summary, the feeding position in the gasifier has a huge impact on the gasification process. It is recommended to use the upward position as it the simpler position and mitigates risks while increases efficiency.

\section{Bed height}

The height of the gasifier is consisting of both the bed and the adjacent freeboard [43]. The bed height is an important design parameter, due to the gasification reactions being slower than combustion reactions, so it needs a deeper bubbling-bed gasifier instead of a bubbling-bed in the combustor [7]. 
The bed height depends on several economics' aspects such as higher beds mean high-pressure losses, taller reactor, and fluidization dynamics [43]. In the fluidized bed gasifier, the effect of bed height has increased the pressure which leads to great gas bubbles and reduced heat transfer coefficients [44]. Yupeng Et al. [45] investigated the pressure drop of Geldart's group B particles and minimum fluidization velocity with different column diameters and bed heights, they reported at decreasing bed diameters and increasing bed height the wall effect was increased, rise minimum fluidization velocity and pressure. Other research experimented the minimum fluidization velocity increase with increasing bed height [46]. Higher bed height permits longer gas retention time which is considered an advantage. However, when the depth is greater than the diameter, it causes slugging. The advantage of long retention time is that it allows further heat transfer, resulting in an increase in the conversion of tar and char to product gas. Even so, short retention time yields small quantity release of volatile matter which can damage the integrity of the process.

The overall height of the bed in the gasifier plays a major role in the process, and therefore it is important to use an appropriate height to achieve optimum results [43][45][46].

\section{Biomass particle size}

In gasification process, the energy efficiency is increased by reducing the particle size, however it also increases the cost of the processes [47]. According to Warnecke, [48] to reduce the particle size for a 5-10 MWe gasification plant, about 10\% of the produced energy is required.

Smaller particles results in higher surface area, which improves mass and heat transfer through them [49]. Additionally, the efficiency of gasification reactions, namely the Boudouard reaction, water gas reaction and carbon conversion, are improved as a result of effective heat transfer.

Furthermore, decreasing the particles sizes, both the hydrogen and carbon monoxide content increase, also it reduces the $\mathrm{CO} 2$ content, tar and char [49]. Li et al. [50] used different particle size in the range of 0.15 to $5 \mathrm{~mm}$. It was found that small particles produced extra $\mathrm{H} 2$ and $\mathrm{CO} 2$ and lower $\mathrm{CH} 4, \mathrm{CO}$ when compared to using larger particles. Otherwise, the maximum value of LHV was gained by utilizing large particles size [50].
Inayat et al. [51] investigated a downdraft gasifier of wood chips/coconut shells with particles sizes of 5-10, 10-25 and 25-50 $\mathrm{mm}$. The outcomes show a higher gas yield of $\mathrm{H} 2, \mathrm{CO}$, and $\mathrm{CH} 4$, as well as HHV using the 5-10 $\mathrm{mm}$ particle size [51].

Similarly, Jia et al. [52]performed the same test but under diverse operation conditions, bed-to-surface heat transfer of three kinds of biomass (Douglas fir, pine, and switchgrass) in a fluidized bed was studied. It also proved that small particles of biomass lead to faster heat transfer and smooth fluidization [52]. Jand et al. [53]found through a study of the influence of particles size in fluidized bed gasification that the quantity of the $\mathrm{CO}$ and carbon content in the product was decreased, whilst char and $\mathrm{CO} 2$ increased, as a result of the large particles is tended to char combustion, which speeds the freeing of $\mathrm{CO} 2$.

Using a research-scale fluidized bed, Fremaux et al. [54] studied hydrogen-rich gas production via steam gasification of biomass with three particles sizes: $0.5-1,1-2.5$ and $5 \mathrm{~mm}$ of wood residue at $900{ }^{\circ} \mathrm{C}$. They observed that $\mathrm{H} 2$ yield improved using small particles due to the heat transfer resistance was decreased with the small size of biomass [54]. Other studies has looked into the effect of different particles sizes of fruit bunch on the ranges of higher than or equal to $0.2 \mathrm{~mm}$ and lower than $2 \mathrm{~mm}$ on producer gas, carbon conversion and high heating value in a fluidized bed at $800 \mathrm{oC}$, the outcome indicated that the $\mathrm{H} 2$ and $\mathrm{CO}$ compositions, producer gas yield, high heating value and carbon conversion increased when particles size decreased [55].

It is evidenced through various research and experiments that using smaller particles in the gasification process yields more efficiency [47][48][49][50][55]. The main reason is that crushing the particles to smaller sizes, ideally between $1-5 \mathrm{~mm}$ in diameter would in fact offer much higher surface area allowing more efficient mass and heat transfer [47][48][49][50][55].

\section{Gasifier Design}

In gasification processes, reactor design is critical for composition, efficiency, and heating value of the product gas, also for the formation of tar. According to Siedlecki et al. [56] there are three types of gasifier used in biomass gasification. The first type is fixed-bed gasifiers, which is split into three further types based on the feeding position; updraft, downdraft and cross-draft gasifiers. The 
second type is the Entrained flow gasifiers, while the third type is the spout fluidised bed gasifier. The latter consists of different set ups based on the bed type, namely, bubbling or circulating fluidised bed. The beds types are discussed further below.

\section{Fixed Bed Gasifiers}

The fixed bed gasifiers type is the simplest and oldest technology in this field [57]. It has been used and studied, mostly for small scale production, due to its construction ease and relatively simple operation, whilst yielding high thermal efficiency and lower pre-treatment of the biomass feedstock [58].

From the reactor technology aspect, the fixed bed has a large temperature distribution across its design [59]. This results in a longer time for heating up, finite scale-up, low specific capacity, hot spots and ash fusion. It is complicated to maintain consistent operation temperatures while keeping sufficient gas mixture in the bed. As a result, the gas yield is unpredictable.

As mentioned, the types of the fixed bed gasifiers are the updraft, downdraft and cross draft ones due to the place of the gasifying agent enters the gasifier [60]. The types are discussed in more details below:

- Updraft gasifier: The feedstock and gasification agent (air or oxygen) shift in the cross direction [61]. The raw material (i.e. biomass) feeds from the upper point in the gasifier while the Gasifying agent enters from the distributor located in the downside of the gasifiers.

It considers to be the simplest gasifier and has a low-cost process [61]. In this method as illustrated in Figure (5), the combustion (Oxidation) takes place at the bottom, which is the highest temperature in the reactor. Further, on the top of the gasifier, the drying and pyrolysis occur [61]. It is important to ensure the removal of the moisture in the feedstock by using hot product gases, which exit from the top of the gasifier.

The advantage of updraft gasifier is its ability to operate with different raw materials [60]. On the other hand, according to Wang et al. [62] the restriction of the updraft gasifiers is its high tar in syngas, low syngas yield and extended start-up time.

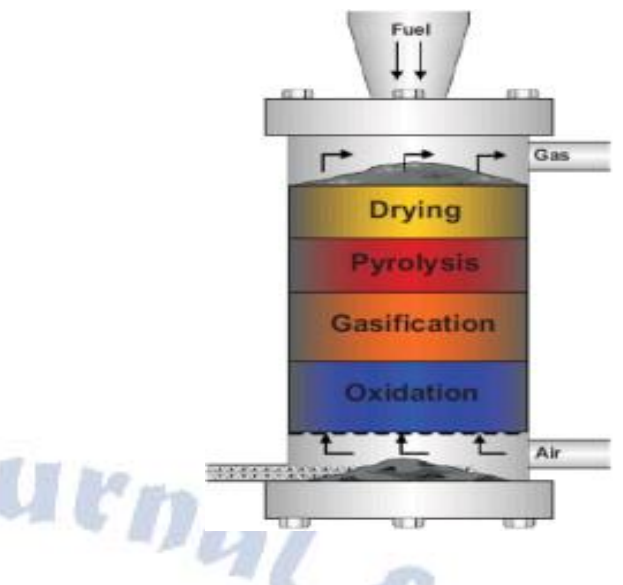

Figure (5): Fixed-bed updraft gasifier [63].

\section{- Downdraft fixed bed gasifier:}

The biomass (fuel) and gas shift enters in one direction and the product gas is flowing out from the bottom as shown in Figure (6) [64]. This process called downdraft fixed bed gasifier. The amount of tar in the product in the updraft gasifiers is the main problem in this gasifier, this can be overcome by inserting the gasifying agent above or at the oxidation zone in the gasifier [64]. According to Sayigh, [65] the products from both the down and updraft gasifiers, especially $\mathrm{CO}, \mathrm{H} 2$, $\mathrm{CH} 4$ and $\mathrm{CO} 2$ are comparatively clean and without or less quantity of tars. which allowed to use in the application in heat and power generation using gas turbines [65]. The benefit of the downdraft fixed-bed gasifier is no or low amount of tar due to cracking down in the oxidation zone. On the other hand, the product needs to clean as it runs the risk of having contaminates such as ash and fine particles [66]. According to Chandolias et al. [67] the downdraft process is less thermally efficiency when compared with updraft as a result of the product from devolatilization do not go through the highest temperature of the gasifier.

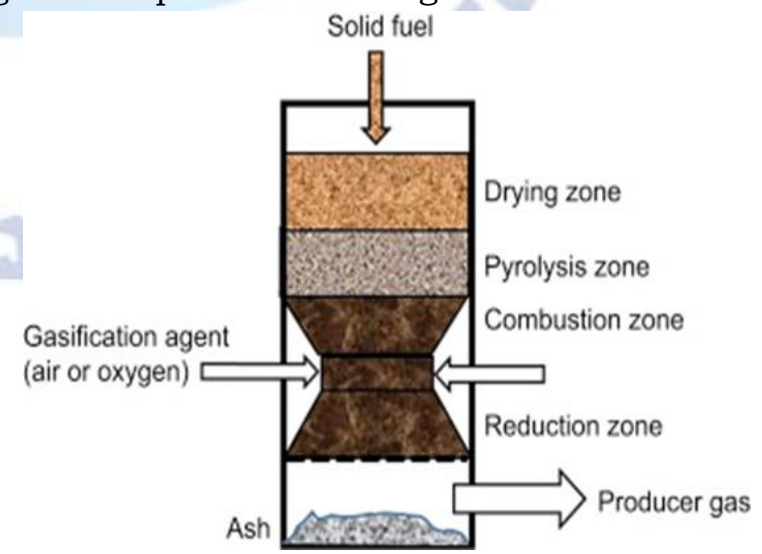

Figure (6) Sketch of the downdraft fixed-bed gasifiers [68]. 


\section{- Cross draft gasifier:}

The feeder (biomass) is fed from the top of the gasifier and the gasifying agent if from the side as shown in Figuer (7). The idea of cross draft is the fuel shifting down the different zones in the gasifier (drying, pyrolysis) and finally gasified whilst the air exits from the other side of the gasifier [69].

The product gas exits almost at the same level of its entrance [69]. The advantage of the cross-draft gasifier is its short start-up time relative to both the updraft and downdraft gasifiers, however, it is only applicable for low volatile content (e.g. charcoal) [70] [71].

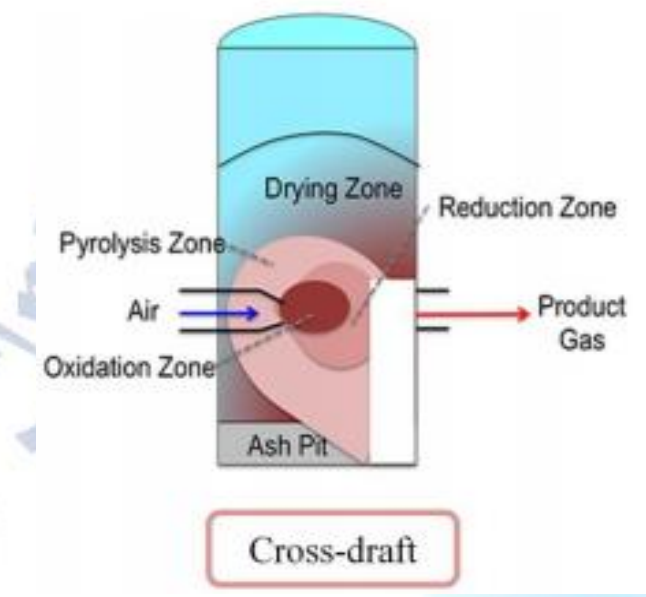

Figure 2-6 Sketch of the Cross-draft gasifier [72].

\section{Fluidised Bed Gasifiers}

Fluidised bed gasifier consists of combustion of solid fuel in static material bed such as sand, which will be tested in this study, it is fluidised owing to gas flow [73]. The hydrodynamics in the fluidised bed gasifier causes a strong mixing for new particles with old ones and promotes even temperature distribution throughout the bed [74]. Fluidised bed gasifiers are used in large scale applications for biomass thermochemical conversion as a result of their capability to high heat and mass transfer rates, a continuation of production [75]. Fluidisation is used in different applications like pyrolysis, gasification, and combustion of various feedstocks such as biomass [76].

The efficiency of heat exchange in fluidised bed reactor and temperature control is better when compared to fixed beds [77]. Belgiorno et al. [78] stated that the fluidised bed performance is about five-time that of fixed bed gasifiers. Due to high mixing rates in a fluidised bed gasifier, there are no different reaction zones, on the contrary to fixed bed gasifiers. Moreover, the fluidised beds are confirmed as the best thermal conversion of various kinds of biomass fuel because it supplies adequate mass and heat transfer for the reactants [79]. As mention above, the fluidised bed gasifier is classified as follows:

\section{Spout fluidised bed gasifier}

The spout fluidised bed structure is shown in figure (8). Historically, it has been used in the chemical and petrochemical industry [79]. More recently, they have been extended to different thermochemical processes such as gasification, combustion, and pyrolysis [79][80].

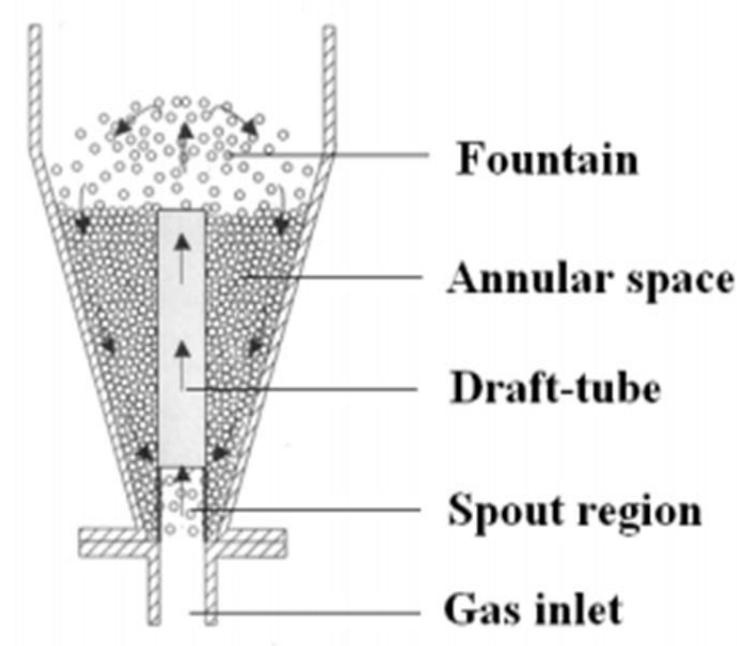

Figure 2-7 Spout Fluidised Bed Reactor [81].

A typical spout bed includes a conical vessel with an orifice in the base of the conical. in the spout bed, there are two regions, the spout, and the annulus. the spout is centric of the conical vessel where the particles in a low-density phase as a result of high fluid velocity which entranced from the office [81].

After reaching the highest level of the reactor (above the bed), the particles fall onto the annulus, which is made of high particle density, resulting in a slow downward motion. Thus a systematic cyclic pattern of particles is founded, with contact between the fluid (biomass) and particles, and with unrivalled hydrodynamics [82][83]. 
The main difference between the spout fluidised bed and the fluidised bed is the dynamic behaviour of the solid particles in each reactor [84]. In the spouted bed a circle, a consistent motion is established with active connection between the gas and the solids involved. The benefit of using spout bed is its ability to handle high ash content ensuring appropriate amounts to gasify different fuels types [85].

Moreover, it has the capability to accommodate various fluidisation velocities without risking severe slugging, which minimizes the capacity of the gasification system. Furthermore, rising the fluidization rate leads to accelerate the fluid-solid contact in the annular regions and reduces the particles agglomerating and sticking to the wall of the vessel [86].

Spouted beds have the minimum spouting velocity, similar to the fluidised bed reactors. Nevertheless, spouted bed space is limited due to maximum spouted bed height [87], while no maximum height can be established in spouted fluidised bed because it relies on the diameters of gas inlet and particle. Even so, the spout bed height is increased when the contactor angle increases, and the particle size decreases [88] [89].

\section{Bubbling fluidised bed gasifier.}

The bubbling fluidized-bed (BFB) is shown in Figure (2-8), the gasifying agent is entered from the bottom of the gasifier and the product is exited from the top whilst the fuel is inserted to the bed [90].

Historically, in 1921, Fritz Winkler has developed the BFB gasifier and it has been used commercially for coal gasification [7]. According to Basu. BFB are deemed the popular technologies for biomass [7].

As illustrated in Figure (9) BFB contains screw feeders, a fluidised bed with a freeboard column unit, air blower, gas plenum (gas box), the distributor plate, and cyclone. The particles In BFB gasifier are kept in a state of suspension by enough velocity of gasification agent through a bed. The raw material (biomass) are entered into the hotbed to mixed and heated up to the bed temperature [91].

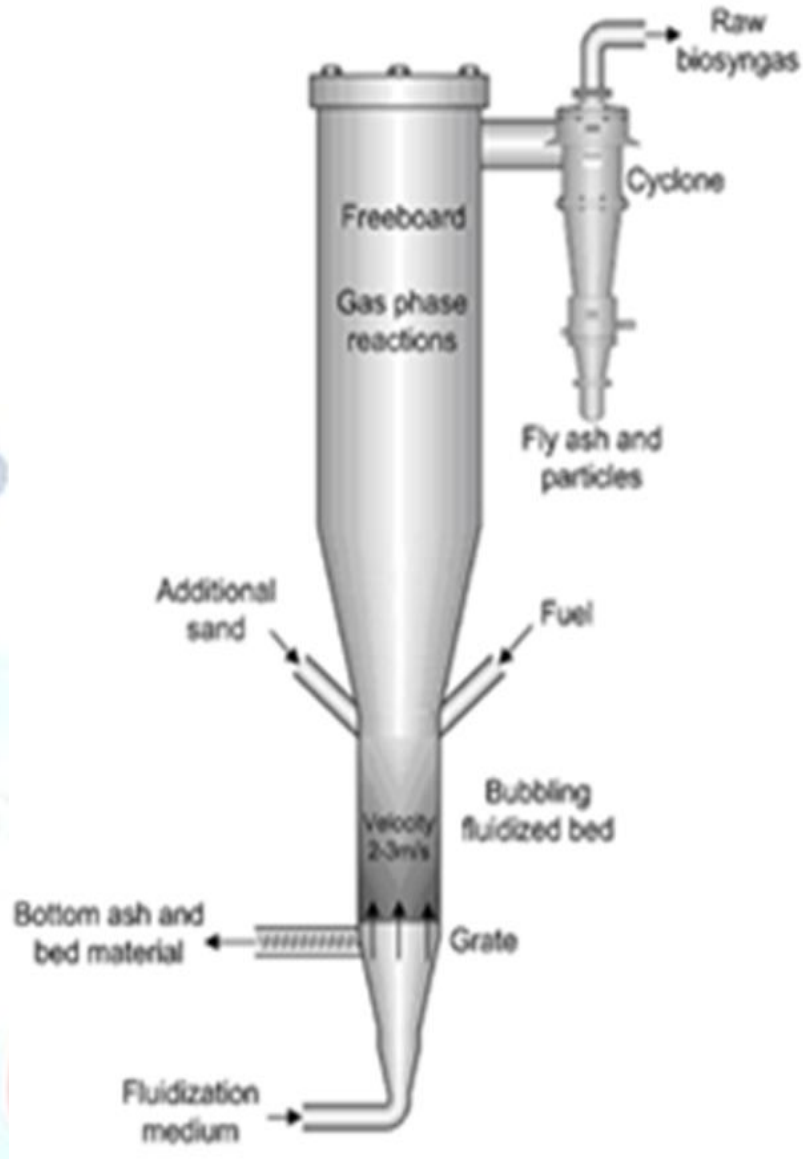

Figure (9): Bubble Fluidised Bed Gasifier [92].

The advantages of BFBs when utilised to convert biomass into energy are: (1) a high degree of random, (2) high gas-solid interaction, (3) good mass, heat transfer, and (4) effective temperature distribution; increased volumetric capacity and heat storage [93].

Moreover, a catalytic agent can be added in the BFB and operated at partial load. The bubbling fluidised beds are adequate and economic for continuous biomass gasification, Further, In BFBS it can be utilised with different biomass and particle sizes including pulverized [94]. Additionally, the gas product from BFBs has low tar content and low unconverted carbon [94].

On the other hand, the BFBs are sensitive to ash content, unlike the spout-fluid bed. The risk of agglomeration increases when biomass has a relatively higher content of ash and the temperature inside the gasifier is higher than 950 ${ }^{\circ} \mathrm{C}[95]$. The higher temperature rises the bed de-fluidization and reduces the efficiency of the gasifier, so the highest temperature is restricted by the melting point of the bed material. The gasification reactions do not reach their chemical equilibrium as a result of low temperature and 
short gas residence times, except when using a catalyst [95]. According to Alberto et al. the operation range in $\mathrm{BFB}$ is among the minimum fluidisation velocity and the velocity on which the bed particle would be dragged by the passing gas, being usually $1.2 \mathrm{~m} / \mathrm{sec}$ [96].

The yields of gaseous fuel in BFBs with using air as the gasifying agent have comparatively high heating values, and minimum to no heat added to the gasifier, which considers as a promising technique [97].

\section{Circulating fluidised bed}

Due to the limitation of bubble fluidised bed gasifier in handling a high level of solid material mixing, a low solid conversion rate is observed [98]. The extension of a recirculating loop improves the conversion by returned unreacted particles to the reaction zone through a cyclone, thus leading to improved solid residence time [99].

According to Yang, circulating fluidised bed (CFB) Figure (2-9) has been used for the gas-solid process since the 1970s [100]. CFB has a wide application in the industry, mainly for biomass and coal gasification [101]. Sikarwar et al. [102] reported that CFBs can deal with high quantity of biomass in different pressure ranges. The high velocity of the stream with recirculation leads to rising mixing which also increases the heat and mass transfer inside the gasifier. Thus, improve the quality of the product gas due to the near optimum environment formed in the gasification [103].

According to Basu.[7] the fluidization velocity in a CFB is much higher than the types mentioned above, as it goes up to $3.5-5.5 \mathrm{~m} / \mathrm{s}$, for context the velocity in a bubbling bed reactor is $0.5-1.0 \mathrm{~m} / \mathrm{s}$. Moreover, the carbon conversion in the CFB is greater than $\mathrm{BFB}$ due to the rising speed of the recirculation and perfect mixing of material [104]. On the other hand, the high gas velocity in the $\mathrm{CBF}$ increases the corrosion rates when compared with BFB [105]. In addition, a CFB involves higher cost, increased the height of the reactor, catalyst agglomeration, and complication in design, construction and operation [106].

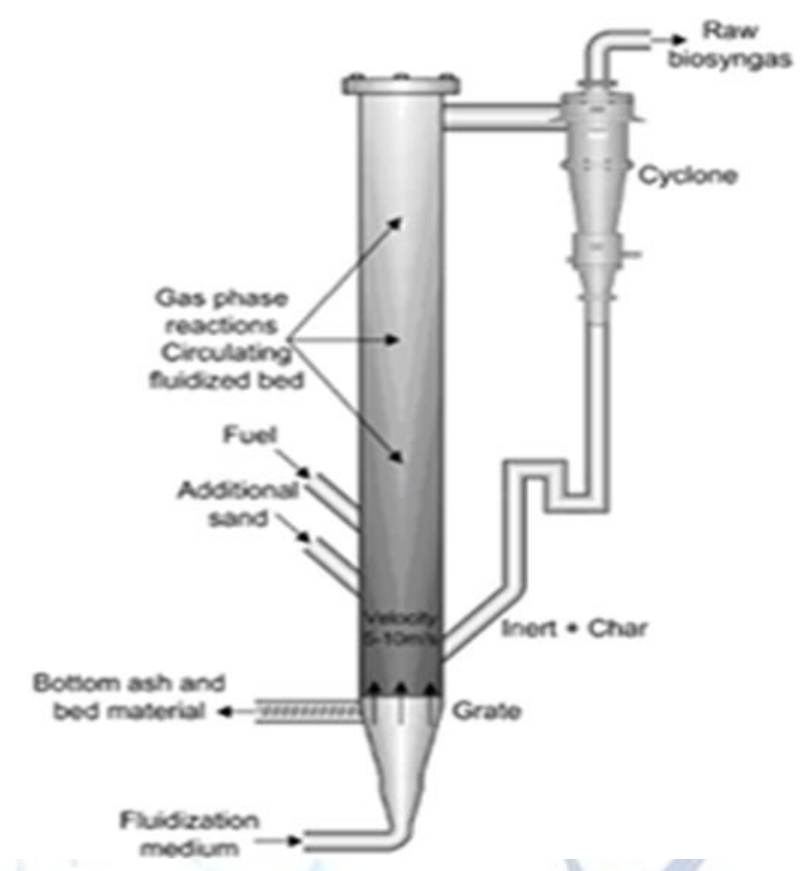

Figure 2-9 Circulating Fluidised Bed Reactor

\section{CATALYTIC PROCESSING OF GASIFICATION PRODUCT GAS}

\section{Catalysis overview}

Catalysis can be defined as the study of catalytic reactions, essentially the description of any material that may accelerate or increase the efficiency of a chemical reaction without impacting it equilibrium and thermodynamics [107]. Catalysis plays an important role in manufacturing, environmental protection and sustainable development [108]. Different types of catalyst are used in the commercial sector, including heterogeneous catalysts (solid), and homogeneous catalysts (liquid) [109].

Historically, a catalyst was used in the industry since 1746 by J. Roebuck [110], and since in different industrial processes such as the purification of crude oil and biomass gasification [110]. Heterogeneous catalysts are widely utilised in gasification processes due to their capability to resist higher temperatures. The aim of using a catalyst in gasification processes is to enhance the quality of the product gas in terms of heating value, enhancing the desired gas ratio and reduce impurities. According to Shahbaz et al. [111] for commercial biomass gasification processes, the perfect catalyst for tar reduction, higher product 
yield and active life of the catalyst are still in debate and is undergoing research.

Basically, Mineral based, and synthesized catalyst are the main types of catalysts which can used biomass gasification, as shown in Figure (11) [111].

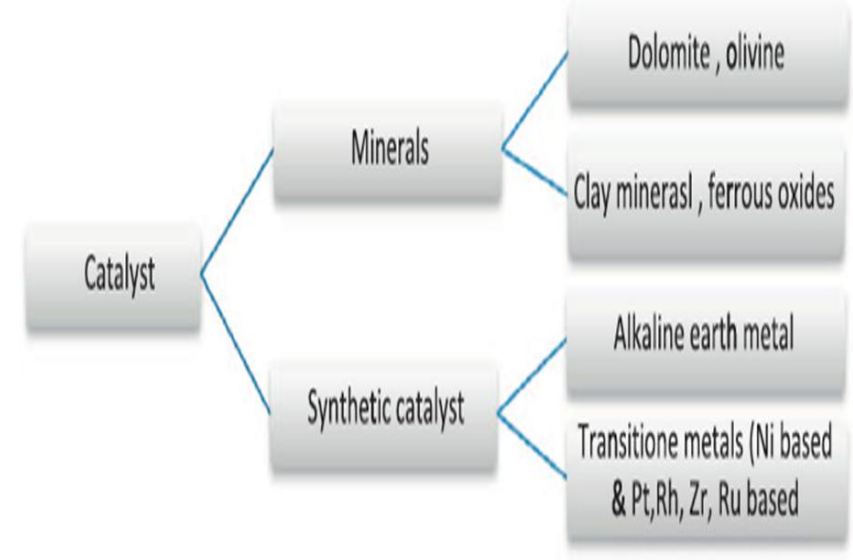

Figure (11): Types of catalyst used in steam biomass gasification.

According to Dayton [112] dolomites are considered to be the most widely non-metallic catalysts used in biomass gasification processes. Therefore, Tian et al. [113] compared the catalytic properties between calcined dolomite and olivine during biomass gasification for tar reduction and syngas production during biomass gasification. This resulted in more clarification in the available catalysts for a more efficient biomass gasification process, which is discussed in the following section.

\section{Steps in heterogeneous catalytic reactions}

Catalytic reactions that utilises heterogeneous catalysts involve separate step, each step is either of chemical or physical nature. The chemical reactions take place when the reactants are in contact with the active sites. The transport of reactants to the active sites is promoted by physical processes namely: diffusion, adsorption and desorption. Typical steps for heterogeneous catalysts are [114]:

i. Diffusion of the feed materials to the surface of the catalyst.

ii. Diffusion of the feed materials into the support pores.

iii. Adsorption of the reactants on the inner surface of the pores.

iv. Chemical reaction on the catalyst surface. v. Desorption of the products from the catalyst surface.

vi. Diffusion of the products out of the pores. vii. Diffusion of the products from the catalyst surface.

Using a catalyst depends on the adsorption of the reactants and desorption of the products. The rate of adsorption increases with increasing the reactor's temperature. Therefore, the catalytic reactor's temperature needs to be carefully controlled to protect the reproducibility of the experiment.

\section{Factors affecting catalyst performance}

Most heterogeneous catalysts lose activity during the catalytic process. The common causes of loss of catalytic activity are fouling, poisoning, sintering, attrition and loss due to vaporisation of active sites. Fouling and poisoning cause similar effects on catalyst performance; fouling refers to a physical coverage of active sites by either trace materials in the feed or the feed materials. These foreign materials can undergo chemical adsorption (chemisorption's) forming a strong adsorptive bond with the catalyst surface, thus covering the active sites, this is also known as catalyst poisoning. In biomass gasification, catalyst poisoning is caused by the deposition of carbon (coking). Carbon deposits on catalysts originates from hydrocarbons contained in the producer gas and the by-products formed during the catalytic reaction. Coking of catalyst depends on the oxygen storage capacity (OSC), which is the ability of the catalyst to absorb and release oxygen at elevated temperatures[115]. Increasing OSC in a catalyst can reduce the coking problems through oxidation process. Moreover, a deactivated catalyst can be regenerated by a controlled combustion of the carbon layer.

Another potential set back is sintering. It is a result of a change of crystallite size of the active sites due to the fusion of particles at higher temperatures. Atoms of any material become mobile and coalescence when heated above the Tamman temperature, which is defined as half of the material melting point, in Kelvin) [116][117].

Increased sintering results in the loss of active surface area, thus, decreasing the catalyst activity. Therefore, the use of catalyst supports with high thermal stability is recommended.

Attrition is defined as the breakup of the catalyst into fine sizes as a result of particle to particle or particle to wall collisions in the fluid-bed reactors. 
The generated fines may transport along with the gas stream or cause blockages. Although supported catalysts in fixed beds are stationary, high abrasion resistance is required to avoid loss of active sites due to attrition.

Another factor that affects the performance of a catalyst is the loss due to evaporation of active sites [114]. This loss is mainly caused by higher operating temperatures of a catalytic reactor. One might be tempted to go for lower temperatures, but lower temperatures can lead to formation of toxic compounds. For instance, at temperatures below $150{ }^{\circ} \mathrm{C}$, nickel catalysts deactivate by forming a highly toxic nickel tetracarbonyl in the methanation of synthesis gas. This implies that, apart from losing the required chemical reaction, poor control of the process temperature may yield unwanted products.

\section{CONCLUSION}

Operating conditions are affecting the gasification reactions. the literature identified that in high-temperature gasification, endothermic reactions the secondary cracking and reforming of heavy hydrocarbons are favoured and hence enhances the whole process's efficiency.

Reducing biomass particle size improves the product gas due to positively influence the heat and mass exchange within the reactor. While ER has several effects on the process, for example lower ER values results in a lower reactor temperature and therefore pyrolysis conditions are met in the biomass reactions. On the other hand, combustion occurs at higher ER, leading to the low heating value of acquired product gas. The gas heating value was improved by using top feeding of biomass, however the amount of tar increased.

A fixed bed and fluidised bed are described. From this literature, a bubble fluidised bed reactor considers as the most suitable technology to gasify the biomass. The range of LHV was between 3.7 and $8.4 \mathrm{MJ} / \mathrm{Nm} 3$, which is suitable for internal combustion engines. So fluidised bed gasifier will be used in this study.

Finally, catalysts are vital for the biomass gasification process, and it is important to select the appropriate ones taking into consideration possible setbacks discussed above and will be explored further in this study.

\section{REFERENCES}

[1] A. Sam, "Toxic Waste From Municipality," Energy from Toxic Org. Waste Heat Power Gener., pp. 7-16, Jan. 2019.

[2]A. Molino, S. Chianese, and D. Musmarra, "Biomass gasification technology: The state of the art overview," J. Energy Chem., vol. 25, no. 1, pp. 10-25, Jan. 2016.

[3]P. Nanou, Biomass gasification for the production of methane. 2013

[4]A. Kumar, D. Jones, and M. Hanna, "Thermochemical Biomass Gasification: A Review of the Current Status of the Technology," Energies, vol. 2, no. 3, pp. 556-581, Jul. 2009.

[5]A. Molino, V. Larocca, S. Chianese, and D. Musmarra, "Biofuels Production by Biomass Gasification: A Review," Energies, vol. 11, no. 4, p. 811, Mar. 2018.

[6]M. A. F. Hamad, A. M. Radwan, and A. Amin, "Review of Biomass Thermal Gasification," in Biomass Volume Estimation and Valorization for Energy, InTech, 2017.

[7]B. Prabis, Biomass Gasification and Pyrolysis - A practical guide. 2010.

[8]D. J. Roddy and C. Manson-Whitton, "Biomass Gasification and Pyrolysis," Compr. Renew. Energy, pp. 133-153, Jan. 2012. [9]M. Tripathi, J. N. Sahu, and P. Ganesan, "Effect of process parameters on production of biochar from biomass waste through pyrolysis: A review," Renew. Sustain. Energy Rev., vol. 55, pp. 467-481, Mar. 2016.

[10] S. C. Moldoveanu and S. C. Moldoveanu, "General Information About Pyrolysis," Pyrolysis Org. Mol., pp. 1-33, Jan. 2019.

[11] R. E. Guedes, A. S. Luna, and A. R. Torres, "Operating parameters for bio-oil production in biomass pyrolysis: A review," J. Anal. Appl. Pyrolysis, vol. 129, pp. 134-149, Jan. 2018.

[12] D. Baruah and D. C. Baruah, "Modeling of biomass gasification: A review,” Renew. Sustain. Energy Rev., vol. 39, pp. 806-815, 2014.

[13] Y. Chhiti and M. Kemiha, "Thermal Conversion of Biomass, Pyrolysis and Gasification: A Review," pp. 75-85, 2013.

[14] Y. S. Pradana and A. Budiman, "BIO-SYNGAS DERIVED FROM INDONESIAN OIL PALM EMPTY FRUIT BUNCH (EFB) USING MIDDLE-SCALE GASIFICATION,” 2014.

[15] U. Arena, "Process and technological aspects of municipal solid waste gasification. A review," Waste Manag., vol. 32, no. 4, pp. 625-639, Apr. 2012.

[16] D. J. Roddy and C. Manson-Whitton, Biomass gasification and pyrolysis, vol. 5. 2012.

[17] H. Boerrigter and R. Rauch, "Review of applications of gases from biomass gasification Justification," 2006.

[18] E. Toklu, "Biomass energy potential and utilization in Turkey," Renew. Energy, vol. 107, pp. 235-244, Jul. 2017.

[19] R. M. Esfahani, W. A. Wan Ab Karim Ghani, M. A. Mohd Salleh, and S. Ali, "Hydrogen-rich gas production from palm kernel shell by applying air gasification in fluidized bed reactor," Energy and Fuels, vol. 26, no. 2, pp. 1185-1191, 2012.

[20] L. Devi, K. J. Ptasinski, and F. J. J. G. Janssen, "A review of the primary measures for tar elimination in biomass gasification processes," Biomass and Bioenergy, vol. 24, no. 2, pp. 125-140, 2003.

[21] Z. A. B. Z. Alauddin, P. Lahijani, M. Mohammadi, and A. R. Mohamed, "Gasification of lignocellulosic biomass in fluidized beds for renewable energy development: A review," Renew. Sustain. Energy Rev., vol. 14, no. 9, pp. 2852-2862, Dec. 2010. [22] J. W. Kook et al., "Gasification and tar removal characteristics of rice husk in a bubbling fluidized bed reactor," Fuel, vol. 181, pp. 942-950, 2016.

[23] J. P. Makwana, J. Pandey, and G. Mishra, "Improving the properties of producer gas using high temperature gasification 
of rice husk in a pilot scale fluidized bed gasifier (FBG)," Renew. Energy, vol. 130, pp. 943-951, 2019.

[24] M. Cortazar et al., "Role of temperature on gasification performance and tar composition in a fountain enhanced conical spouted bed reactor," Energy Convers. Manag., vol. 171, no. April, pp. 1589-1597, 2018.

[25] A. Z. Yahaya, M. R. Somalu, A. Muchtar, S. A. Sulaiman, and W. R. Wan Daud, "Effect of particle size and temperature on gasification performance of coconut and palm kernel shells in downdraft fixed-bed reactor," Energy, vol. 175, pp. 931-940, 2019.

[26] E. S. Aydin, O. Yucel, and H. Sadikoglu, "Experimental study on hydrogen-rich syngas production via gasification of pine cone particles and wood pellets in a fixed bed downdraft gasifier," Int. J. Hydrogen Energy, vol. 44, no. 32, pp. 17389-17396, 2019.

[27] S. M. Beheshti, H. Ghassemi, and R. Shahsavan-Markadeh, "Process simulation of biomass gasification in a bubbling fluidized bed reactor," Energy Convers. Manag., vol. 94, pp. 345-352, Apr. 2015.

[28] D. Baruah and D. C. Baruah, "Modeling of biomass gasification: A review," Renew. Sustain. Energy Rev., vol. 39, pp. 806-815, 2014.

[29] H. Ghassemi and R. Shahsavan-Markadeh, "Effects of various operational parameters on biomass gasification process; A modified equilibrium model," Energy Convers. Manag., vol. 79, pp. 18-24, 2014.

[30] M. A. Hamad, A. M. Radwan, D. A. Heggo, and T. Moustafa, "Hydrogen rich gas production from catalytic gasification of biomass," Renew. Energy, vol. 85, pp. 1290-1300, Jan. 2016.

[31] J. G. Speight and J. G. Speight, "Gasifier Types," Gasif. Unconv. Feed., pp. 54-90, Jan. 2014.

[32] A. M. Radwan, "Ver important amount of steam Pelagia Research Library An overview on gasification of biomass for production of hydrogen rich gas," vol. 3, no. 2, pp. 323-335, 2012.

[33] E. Shayan, V. Zare, and I. Mirzaee, "Hydrogen production from biomass gasification; a theoretical comparison of using different gasification agents," Energy Convers. Manag., vol. 159, no. December 2017, pp. 30-41, 2018.

[34] A. Mustafa, R. K. Calay, and M. Y. Mustafa, "A Techno-economic Study of a Biomass Gasification Plant for the Production of Transport Biofuel for Small Communities," Energy Procedia, vol. 112, no. October 2016, pp. 529-536, 2017.

[35] P. Parthasarathy and K. S. Narayanan, "Hydrogen production from steam gasification of biomass: Influence of process parameters on hydrogen yield - A review," Renew. Energy, vol. 66, pp. 570-579, Jun. 2014.

[36] F. Pinto, R. André, M. Miranda, D. Neves, F. Varela, and J. Santos, "Effect of gasification agent on co-gasification of rice production wastes mixtures," Fuel, vol. 180, pp. 407-416, Sep. 2016.

[37] P. Parthasarathy and K. S. Narayanan, "Hydrogen production from steam gasification of biomass: Influence of process parameters on hydrogen yield - A review," Renew. Energy, vol. 66, pp. 570-579, Jun. 2014.

[38] V. Kirsanovs, D. Blumberga, I. Veidenbergs, C. Rochas, E. Vigants, and G. Vigants, "Experimental investigation of downdraft gasifier at various conditions," Energy Procedia, vol. 128, pp. 332-338, Sep. 2017.

[39] V. S. Sikarwar et al., "An overview of advances in biomass gasification," Energy Environ. Sci., vol. 9, no. 10, pp. 2939-2977, Oct. 2016.

[40] A. A. P. Susastriawan, H. Saptoadi, and Purnomo, "Small-scale downdraft gasifiers for biomass gasification: A review," Renew. Sustain. Energy Rev., vol. 76, pp. 989-1003, Sep. 2017.

[41] R. Luque, C. S. Ki Lin, K. Wilson, and J. Clark, Handbook of Biofuels Production. Process and Technologies. 2016.

[42] H. A. Choudhury, S. Chakma, and V. S. Moholkar, "Biomass Gasification Integrated Fischer-Tropsch Synthesis: Perspectives, Opportunities and Challenges," Recent Adv. Thermo-Chemical Convers. Biomass, pp. 383-435, Jan. 2015. [43] P. J. van den Enden and E. S. Lora, "Design approach for a biomass fed fluidized bed gasifier using the simulation software CSFB.," Biomass and Bioenergy, vol. 26, no. 3, pp. 281-287, 2004.

[44] J. Karl and T. Pröll, "Steam gasification of biomass in dual fluidized bed gasifiers: A review,” Renew. Sustain. Energy Rev., vol. 98, pp. 64-78, Dec. 2018.

[45] Y. Xu, T. Li, J. Musser, X. Liu, G. Xu, and W. A. Rogers, "CFD-DEM modeling the effect of column size and bed height on minimum fluidization velocity in micro fluidized beds with Geldart B particles," Powder Technol., vol. 318, pp. 321-328, Aug. 2017.

[46] Z. Fu, J. Zhu, S. Barghi, Y. Zhao, Z. Luo, and C. Duan, "Minimum fluidization velocity growth due to bed inventory increase in an Air Dense Medium Fluidized Bed," Chem. Eng. J., vol. 359, pp. 1372-1378, Mar. 2019.

[47] P. Parthasarathy and K. S. Narayanan, "Hydrogen production from steam gasification of biomass: Influence of process parameters on hydrogen yield e A review," 2014.

[48] R. Warnecke, "Gasi ${ }^{\circledR}$ cation of biomass : comparison of ${ }^{\circledR}$ xed bed and - uidized bed gasi ${ }^{\circledR}$ er," vol. 18, 2000.

[49] J. J. Hernández, G. Aranda-Almansa, and A. Bula, "Gasification of biomass wastes in an entrained flow gasifier: Effect of the particle size and the residence time," 2010.

[50] S. H. Lee, R. T. L Ng, D. K. S Ng, D. C. Y Foo, I. M. L Chew, and S. Liu, "Black liquor gasification integrated in pulp and paper mills: A critical review," John Wiley \& Sons, 2013.

[51] M. Inayat, S. A. Sulaiman, and A. Kumar, "Effect of fuel particle size and blending ratio on syngas production and performance of co-gasification Design and development of solar desalination plant View project Hydrodynamics of Swirling Fluidized Bed with Sloping Distributor View project," 2016.

[52] D. Jia, X. Bi, C. J. Lim, S. Sokhansanj, and A. Tsutsumi, "Heat transfer in a tapered fluidized bed of biomass particles with pulsed gas flow," Particuology, vol. 42, pp. 2-14, Feb. 2019. [53] N. Jand and P. U. Foscolo, "Decomposition of Wood Particles in Fluidized Beds," 2005.

[54] S. Fremaux, S.-M. Beheshti, H. Ghassemi, and R. Shahsavan-Markadeh, "An experimental study on hydrogen-rich gas production via steam gasification of biomass in a research-scale fluidized bed," Energy Convers. Manag., vol. 91, pp. 427-432, Feb. 2015.

[55] M. A. M. Salleh, H. K. Nsamba, H. M. Yusuf, A. Idris, W. A. Wan, and A. K. Ghani, "Effect of Equivalence Ratio and Particle Size on EFB Char Gasification," vol. 37, pp. 1647-1662, 2015. [56] M. Siedlecki, W. De Jong, and A. H. M. Verkooijen, "Fluidized Bed Gasification as a Mature And Reliable Technology for the Production of Bio-Syngas and Applied in the Production of Liquid Transportation Fuels-A Review," Energies, vol. 4, no. 3, pp. 389-434, Mar. 2011.

[57] T. M. Ismail and M. A. El-Salam, "Numerical and experimental studies on updraft gasifier HTAG," Renew. Energy, vol. 78, pp. 484-497, Jun. 2015.

[58] Y. Richardson, M. Drobek, A. Julbe, J. Blin, and F. Pinta, "Biomass Gasification to Produce Syngas," Recent Adv. Thermo-Chemical Convers. Biomass, pp. 213-250, Jan. 2015. [59] R. Warnecke, "Gasification of biomass: comparison of fixed bed and fluidized bed gasifier," Biomass and Bioenergy, vol. 18, no. 6, pp. 489-497, Jun. 2000. 
[60] S. Chopra and A. K. Jain, "A Review of Fixed Bed Gasification Systems for Biomass," 2007.

[61] C. Mandl, I. Obernberger, and F. Biedermann, "Modelling of an updraft fixed-bed gasifier operated with softwood pellets," Fuel, vol. 89, no. 12, pp. 3795-3806, Dec. 2010.

[62] J. Wang, N. Liu, X. Wang, Y. Gao, G. Wang, and L. Li, "Energy Sources, Part A: Recovery, Utilization, and Environmental Effects Application of updraft biomass gasifier for non-ferrous metal smelting," 2018.

[63] C. Mandl, I. Obernberger, and F. Biedermann, "Modelling of an updraft fixed-bed gasifier operated with softwood pellets," Fuel, vol. 89, no. 12, pp. 3795-3806, 2010.

[64] Mohandas Mangre, Savita Vyas, and Mukesh Pandey, "Downdraft fixed bed biomass gasifier: A review," Curr. Sci. Perspect., vol. 3, no. 3, pp. 143-147, 2017.

[65] A. A. M. Sayigh, Comprehensive renewable energy.

[66] S. Pang, "Fuel flexible gas production: Biomass, coal and bio-solid wastes," Fuel Flex. Energy Gener., pp. 241-269, Jan. 2016.

[67] K. Chandolias, T. Richards, and M. J. Taherzadeh, "Combined Gasification-Fermentation Process in Waste Biorefinery," Waste Biorefinery, pp. 157-200, Jan. 2018.

[68] S. Pang, "Fuel flexible gas production: Biomass, coal and bio-solid wastes," Fuel Flex. Energy Gener., pp. 241-269, Jan. 2016.

[69] H. A. Choudhury, S. Chakma, and V. S. Moholkar, "Biomass Gasification Integrated Fischer-Tropsch Synthesis: Perspectives, Opportunities and Challenges," Recent Adv. Thermo-Chemical Convers. Biomass, pp. 383-435, Jan. 2015. [70] S. Mahapatra, "Experiments and Analysis on Wood Gasification in an Open Top Downdraft Gasifier," no. March, 2016.

[71] S. Bakheet, S. Kamel, H. A. El-Sattar, and F. Jurado, "Different Biomass Gasification Reactors for Energy Applications," in 2018 20th International Middle East Power Systems Conference, MEPCON 2018 - Proceedings, 2019, pp. 660-665.

[72] "Cross Draft Gasification | Biofuels Academy." [Online]. Available:

http:/ / biofuelsacademy.org/index.html\%3Fp=504.html.

[Accessed: 04-Oct-2019].

[73] C. G. Philippsen, A. C. F. Vilela, and L. D. Zen, "Fluidized bed modeling applied to the analysis of processes: review and state of the art," J. Mater. Res. Technol., vol. 4, no. 2, pp. 208-216, Apr. 2015.

[74] I. Janajreh and I. Adeyemi, Effect of Process Parameters on Gasification: Review, no. 9. 2014.

[75] V. K. Guda, P. H. Steele, V. K. Penmetsa, and Q. Li, "Fast Pyrolysis of Biomass: Recent Advances in Fast Pyrolysis Technology," Recent Adv. Thermo-Chemical Convers. Biomass, pp. 177-211, Jan. 2015.

[76] S. B. Sethupathy and E. Natarajan, "Hydrodynamic study on gasification of biomass in a fluidized bed gasifier," Int. J. Eng. Sci. Technol., vol. 4, no. 1, pp. 316-323, 2012.

[77] A. Lappas and E. Heracleous, "Production of biofuels via Fischer-Tropsch synthesis: Biomass-to-liquids," Handb. Biofuels Prod., pp. 549-593, Jan. 2016.

[78] V. Belgiorno, G. De Feo, C. Della Rocca, and R. M. A. Napoli, "Energy from gasification of solid wastes," Waste Manag., vol. 23, no. 1, pp. 1-15, 2003.

[79] M. Öhman, L. Pommer, and A. Nordin, "Bed agglomeration characteristics and mechanisms during gasification and combustion of biomass fuels," Energy and Fuels, vol. 19, no. 4, pp. 1742-1748, 2005.

[80] G. López, M. Olazar, R. Aguado, and J. Bilbao, "Continuous pyrolysis of waste tyres in a conical spouted bed reactor," Fuel, vol. 89, no. 8, pp. 1946-1952, Aug. 2010.
[81] H. Altzibar, G. Lopez, M. Olazar, and J. Bilbao, "Study of the Minimum Spouting Velocity in a Draft Tube Conical Spouted Bed," 13th Int. Conf. Fluid. - New Paradig. Fluid. Eng., pp. 1-9, 2010.

[82] N. Epstein and J. R. Grace, "Spouting of Particulate Solids," in Handbook of Powder Science \& Technology, Boston, MA: Springer US, 1997, pp. 532-567.

[83] P. Basu, "Combustion and gasification in fluidized beds ", 2006.

[84] P. A. Salam and S. C. Bhattacharya, "A comparative study of charcoal gasification in two types of spouted bed reactors," Energy, vol. 31, no. 2-3, pp. 228-243, 2006.

[85] R. Xiao et al., "Air blown partial gasification of coal in a pilot plant pressurized spout-fluid bed reactor," Fuel, vol. 86, no. 10-11, pp. 1631-1640, 2007.

[86] W. Zhong and M. Zhang, "Pressure fluctuation frequency characteristics in a spout-fluid bed by modern ARM power spectrum analysis," Powder Technol., vol. 152, no. 1-3, pp. 52-61, 2005.

[87] C. Gupta and D. Sathiyamoorthy, "Fluid bed technology in materials processing1998“,.

[88] M. Olazar, M. J. S. José, A. T. Aguayo, J. M. Arandes, and J. Bilbao, "Design Factors of Conical Spouted Beds and Jet Spouted Beds," Ind. Eng. Chem. Res., vol. 32, no. 6, pp. 1245-1250, 1993.

[89] I. Estiati, H. Altzibar, M. Tellabide, and M. Olazar, "A new method to measure fine particle circulation rates in draft tube conical spouted beds," Powder Technol., vol. 316, pp. 87-91, Jul. 2017.

[90] S. Pang, "Fuel flexible gas production: Biomass, coal and bio-solid wastes," Fuel Flex. Energy Gener., pp. 241-269, Jan. 2016.

[91] B. Sahoo, "The effect of parameters on the performance of a Fluidized bed reactor and Gasifier The effect of parameters on the performance of a Fluidized bed reactor and Gasifier," no. 209, 2011.

[92] J. Hansson and A. Leveau, "Biomass Gasifier Database for Computer Simulation Purposes,” pp. 1-42, 2011.

[93] M. B. Nikoo and N. Mahinpey, "Simulation of biomass gasification in fluidized bed reactor using ASPEN PLUS," Biomass and Bioenergy, vol. 32, no. 12, pp. 1245-1254, Dec. 2008.

[94] J. P. Ciferno and J. J. Marano, "Benchmarking biomass gasification technologies for fuels, chemicals and hydrogen production," US Dep. Energy. Natl. Energy, no. June, p. 58, 2002.

[95] M. Siedlecki, W. de Jong, and A. H. M. Verkooijen, "Fluidized bed gasification as a mature and reliable technology for the production of bio-syngas and applied in the production of liquid transportation fuels-a review," Energies, vol. 4, no. 3, pp. 389-434, 2011.

[96] J. Alberto and P. Peña, "Bubbling Fluidized Bed ( BFB )," IFSA 2011, Ind. Fluid. South Africa, no. November, pp. 1-12, 2011.

[97] C. Loha, H. Chattopadhyay, and P. K. Chatterjee, "Three dimensional kinetic modeling of fluidized bed biomass gasification," Chem. Eng. Sci., vol. 109, pp. 53-64, 2014.

[98] X. T. Li, J. R. Grace, C. J. Lim, A. P. Watkinson, H. P. Chen, and J. R. Kim, "Biomass gasification in a circulating fluidized bed," Biomass and Bioenergy, vol. 26, no. 2, pp. 171-193, 2004. [99] X. T. Li, J. R. Grace, C. J. Lim, A. P. Watkinson, H. P. Chen, and J. R. Kim, "Biomass gasification in a circulating fluidized bed," Biomass and Bioenergy, vol. 26, no. 2, pp. 171-193, Feb. 2004.

[100]W.-C. Yang, HANDBOOK of FLUIDIZfiTION and FLUID-PARTICLE SYSTEMS, vol. 839, no. 281. 2003. 
[101]M. V. Gil, "Coal and biomass cofiring: fundamentals and future trends," New Trends Coal Convers., pp. 117-140, Jan. 2019.

[102]V. S. Sikarwar and M. Zhao, Biomass Gasification, no. December. Elsevier Inc., 2017.

[103]Z. A. B. Z. Alauddin, P. Lahijani, M. Mohammadi, and A. R. Mohamed, "Gasification of lignocellulosic biomass in fluidized beds for renewable energy development: A review," Renew. Sustain. Energy Rev., vol. 14, no. 9, pp. 2852-2862, Dec. 2010. [104]J. Brown, "Biomass Gasification : Fast Internal Circulating Fluidised Bed Gasifier Characterisation and Comparison," Fuel, vol. 89, no. 2, pp. 384-391, 2006.

[105]Olivier Morin, "Technical and Environmental Comparison of Circulating Fluidized Bed (CFB) and Moving Grate Reactors," p. $47,2014$.

[106]X. Wang, M. Economides, X. Wang, and M. Economides, "Gas-To-Liquids (GTL)," Adv. Nat. Gas Eng., pp. 243-287, Jan. 2009.

[107]A. E. Karim Kakae, iMehdiD.Esrafili, "Introduction to Catalysis," Interface Sci. Technol., vol. 27, pp. 1-21, Jan. 2019. [108]A. Dabrowski, "Adsorption - its development and application for practical purposes," Stud. Surf. Sci. Catal., vol. 120, pp. 3-68, Jan. 1999.

[109]A. Hagemeyer and A. Volpe, "Materials: Catalysts," Ref. Modul. Mater. Sci. Mater. Eng., Jan. 2016.

[110]R. R, U. V, and L. D, "Green chemistry concept: Applications of catalysis in pharmacuetical industry," Glob. Drugs Ther., vol. 2, no. 4, pp. 1-7, 2017.

[111]M. Shahbaz, S. yusup, A. Inayat, D. O. Patrick, and M. Ammar, "The influence of catalysts in biomass steam gasification and catalytic potential of coal bottom ash in biomass steam gasification: A review," Renew. Sustain. Energy Rev., vol. 73, no. November 2015, pp. 468-476, 2017.

[112]D. Dayton, "Review of the Literature on Catalytic Biomass Tar Destruction: Milestone Completion Report," no. December, 2002.

[113]Y. Tian, X. Zhou, S. Lin, X. Ji, J. Bai, and M. Xu, "Syngas production from air-steam gasification of biomass with natural catalysts," Sci. Total Environ., vol. 645, pp. 518-523, Dec. 2018. [114]J. Hagen, "Industrial catalysis: a practical approach ", 2015.

[115]N. Kakuta, N. Morishima, M. Kotobuki, ... T. I.-A. surface, and undefined 1997, "Oxygen storage capacity (OSC) of aged $\mathrm{Pt} / \mathrm{CeO} 2 / \mathrm{Al} 2 \mathrm{O} 3$ catalysts: roles of $\mathrm{Pt}$ and $\mathrm{CeO} 2$ supported on A12O3," Elsevier.

[116]R. Liu, P. Crozier, C. Smith, ... D. H.-A. C. A., and undefined 2005, "Metal sintering mechanisms and regeneration of palladium/alumina hydrogenation catalysts," Elsevier.

[117]J. Sun, D. Luo, P. Xiao, L. Jigang, S. Y.-J. of P. Sources, and undefined 2008, "High yield hydrogen production from low $\mathrm{CO}$ selectivity ethanol steam reforming over modified Ni/Y2O3 catalysts at low temperature for fuel cell application," Elsevier.

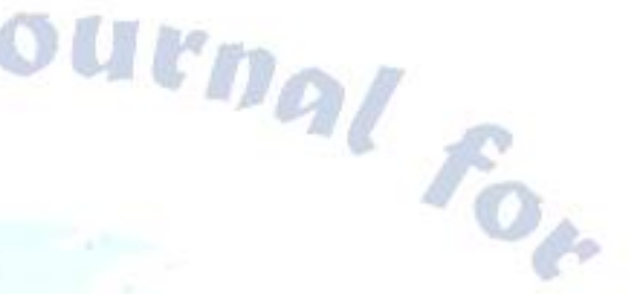

